\title{
First record of the seagrass-boring shipworm Zachsia sp. (Bivalve: Teredinidae) in natural and transplanted Enhalus acoroides (Hydrocharitaceae) rhizomes in tropical Southwest Pacific
}

\author{
NENNI ASRIANI ${ }^{1}$, ROHANI AMBO-RAPPE ${ }^{2, \boldsymbol{v}}$, MAHATMA LANURU ${ }^{2}$ \\ ${ }^{1}$ Doctoral Progam in Fisheries Science, Faculty of Marine Science and Fisheries, Universitas Hasanuddin. Jl. Tamalanrea Km 10, Makassar 90245, South \\ Sulawesi, Indonesia \\ ${ }^{2}$ Department of Marine Science, Faculty of Marine Science and Fisheries, Universitas Hasanuddin. Jl. Tamalanrea Km 10, Makassar 90245, South \\ Sulawesi, Indonesia. Tel./fax.: +62-411-586025, `email: rohani.amborappe@gmail.com
}

Manuscript received: 30 July 2019. Revision accepted: 12 October 2019

\begin{abstract}
Asriani N, Ambo-Rappe R, Lanuru M. 2019. First record of the seagrass-boring shipworm Zachsia sp. (Bivalve: Teredinidae) in natural and transplanted Enhalus acoroides (Hydrocharitaceae) rhizomes in tropical Southwest Pacific. Biodiversitas 20: $3180-$ 3188. Seagrass ecosystems are under threat worldwide. Seagrass transplantation is one restoration approach that has been tried with uneven success. While transplantation methods and oceanographic parameters have been investigated in attempts to understand the factors affecting transplant survival rate and seagrass transplantation success, little attention has been paid to the possible impact of pests. To our knowledge, we report the first record of the seagrass-boring shipworm Zachsia (Teredinidae) in the tropical southwest Pacific. Shipworms were found in rhizomes of the seagrass Enhalus acoroides growing in natural beds and in a transplanted area, in the Spermonde Archipelago, eastern Indonesia. In twelve E. acoroides rhizome samples (average length $10.5 \mathrm{~cm}$ ) we found between one and four burrows lined with calcareous tubes $2 \mathrm{~mm}$ to $5 \mathrm{~mm}$ in diameter inside the rhizome and six Zachsia. Prevalence of Zachsia burrows in exposed versus buried rhizomes was $64 \%$ vs. $4 \%$ in the natural seagrass bed and $100 \%$ vs. $0 \%$ in the seagrass transplants. Further research is required to determine the species present and its distribution in Indonesian waters as well as the true ecological impact of Zachsia sp. on seagrasses.
\end{abstract}

Keywords: Boring molluscs, seagrass health, seagrass rhizome borer, seagrass transplantation, Teredinidae

\section{INTRODUCTION}

Seagrasses are unique among aquatic plants, being the only marine angiosperm group that lives submerged in seawater (den Hartog 1970; Les and Cleland 1997). Seagrasses have a complex and strong root system that enable seagrass beds to trap sediment (Duarte 2002), while the canopy is thought to reduce wave energy (Gacia et al. 2003). Some seagrass species are directly utilized as the main foods consumed by endangered species including marine turtles and dugongs (Lanyon et al. 1989; Fourqurean et al. 2010). Furthermore, seagrass beds provide habitats for economically important fish and invertebrates (Duffy 2006). In particular, epiphytes and epifauna living on seagrasses provide food for herbivorous and carnivorous animals that live in and around the seagrass beds (de la Torre-Castro et al. 2008; Lebreton et al. 2009). In the context of global climate change, seagrasses play an important role as they contribute to natural $\mathrm{CO}_{2}$ capture and sequestration, accounting for approximately $15 \%$ of annual "blue carbon" trapped (Fourqurean et al. 2012; Duarte et al. 2013; Lavery et al. 2013). On average seagrass beds sequester almost three times as much per $\mathrm{km}^{2}$ as rainforests (Fourqurean et al. 2012).

Regrettably, seagrass meadows face threats worldwide, resulting in a reduction in the area covered (Waycott et al. 2009; Short et al. 2011). The most common causes of seagrass loss include direct physical damage from anthropogenic activities (e.g. boat anchors and dredging) (Hossain et al. 2018), destructive fishing (Moore et al. 2017), overfishing, land reclamation, and garbage disposal/ waste discharge to the sea (Unsworth et al. 2018). The loss of seagrass beds has negative impacts on neighboring ecosystems (Marba et al. 2015). It is therefore important to pay attention to the maintenance of healthy seagrass beds through conservation measures, including restoration activities.

At the global level, seagrass restoration is no longer a novel approach to seagrass conservation. Restoration has been carried out in various temperate and tropical countries. Restoration success and its assessment have been addressed from a variety of aspects. However, one aspect which has received little attention to date is the presence of organisms that could interfere with seagrass health and survival and thus rehabilitation viability (Brearley et al. 2008; Mejaes et al. 2015). In other contexts, studies have found several groups of organisms that can bore into and/or graze on the leaves and/or rhizomes of seagrasses. These organisms include boring polychaete worms that bore into the rhizomes and leaf sheaths of Posidonia oceanica in Italy and the Mediterranean Sea (Guidetti 2000; Gambi 2002; Gambi et al. 2005) isopods boring into Thalassia hemprichii leaf sheaths in Tanzania and Posidonia oceanica in Mediterranean (Guidetti 2000; Gambi and 
Lorenti 2009); the mollusc Smaragdia souverbiana grazing on the leaves of Halophila ovalis, Zostera capriconi and Cymodocea serrulata (Rossini et al. 2014); and molluscs of the genus Zachsia (Bulatoff and Rjabtschikoff 1933) boring into the rhizomes of Zostera spp. and Phyllospadix iwatensis in Japan and Russia (Turner et al. 1983; Haga 2006; Shipway et al. 2016) and the rhizomes of Enhalus acoroides Lf. Royle, 1839 and Cymodocea rotundata in Malaysia (Yap et al. 2018). In addition to native pests, introduced (alien) species have also been reported as pests in seagrass meadows (Iannotta et al. 2007; Williams 2007).

It has been suggested that when seagrasses colonized marine waters, they "found a vast new habitat free of terrestrial competitors and insect pests" (Olsen et al. 2016). However, based on the aforementioned studies, it would seem that seagrasses do suffer from a variety of "pests", both native and introduced. Indeed, it is not impossible that seagrasses might suffer a much higher level of infestation than has as yet been realized. In one of region in the tropical southwest Pacific, specifically the Spermonde Archipelago in Indonesia, we found a boring bivalve in an E. acoroides rhizome by chance during seagrass transplant monitoring. These seagrass-borers were subsequently found in both natural seagrass beds and transplanted areas. This study aimed to: (i) Document the borer organisms found in natural seagrass beds and seagrass transplants; (ii) Identify the boring organisms found based on morphological characteristics.

\section{MATERIALS AND METHODS}

\section{Study site}

All fieldwork was conducted in the shallow waters south of Barrang Caddi Island, Spermonde Archipelago, in the tropical southwest Pacific region of Indonesia (Figure 1). The observation site was located at approximately $5^{\circ} 05^{\prime} 05^{\prime \prime} \mathrm{S}$ and $119^{\circ} 19^{\prime} 07^{\prime \prime} \mathrm{E}$ in natural E. acoroides dominated seagrass beds and seagrass transplantation $(E$. acoroides) area, situated approximately 10-50m apart.

Three methods were used at the transplantation site. In method 1, seagrass shoots were attached to a wireframe placed on the substrate; the rhizomes were in contact with the substrate but not buried. In method 2, a shallow trench was dug in the substrate; the rhizomes were laid in the bottom of the trench and fixed firmly in place using metal staples and then covered with the previously removed sediment. The third method also involved digging a trench and burying the rhizomes by replacing the sediment layer; however, instead of stapling the rhizomes in place, sandbags (containing sand mixed with some cement) were placed in a semi-circle around the transplants on the seaward side to provide protection from wave action and currents. The $E$. acoroides transplants were all sourced from the same site in the seagrass meadows around the nearby island of Barrang Lompo (Figure 1). Boring organisms were first observed in the natural seagrass bed on 31 December 2017 and in the seagrass transplants on 17 March 2018.

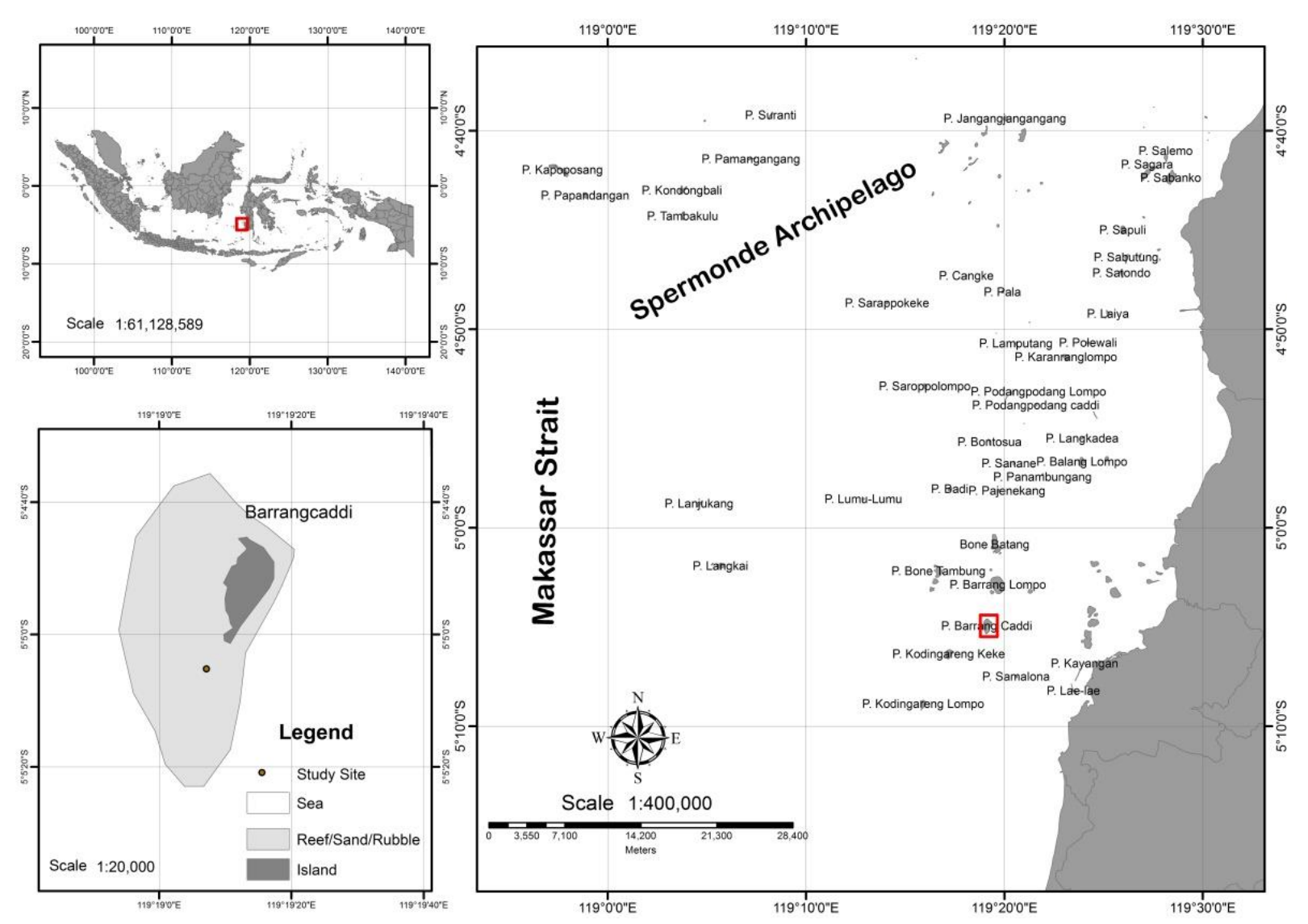

Figure 1. Study sites in Barrang Caddi Island, Spermonde Archipelago, South Sulawesi, Indonesia 


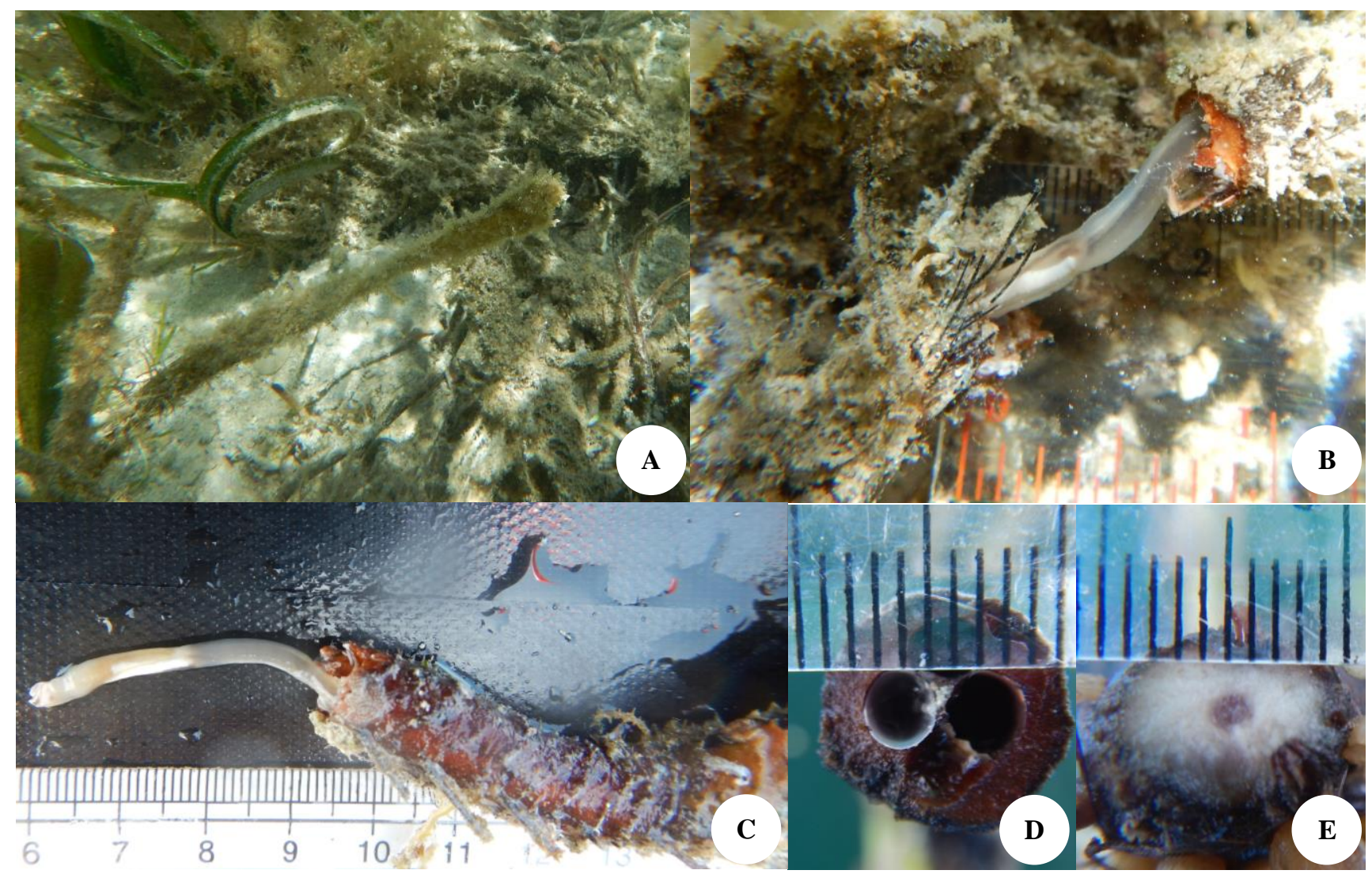

Figure 2. Habitat and specimens of the seagrass-boring mollusc Zachsia: A. Exposed E. acoroides rhizomes in the natural seagrass bed; B. Zachsia visible in an exposed E. acoroides rhizome in situ; C. Zachsia in the rhizome immediately after collection; D. Section of an E. acoroides rhizome bored by Zachsia with ruler to indicate burrow diameter; E. Section of a healthy E. acoroides rhizome.

\section{Sample collection and imaging}

The first seagrass rhizome containing a boring mollusc was found by chance in an exposed rhizome of the seagrass E. acoroides which was seen during restoration monitoring activities on December 31, 2017. The shoot and exposed rhizome were collected out of curiosity. On examination of this specimen, there were 4 burrow entrances visible in the rhizome; each burrow appeared to have a calcareous lining. The rhizomes were carefully broken apart to enable a more detailed observation, revealing the presence of vermiform soft-bodied organisms within 3 of the calcareous tubes, one of which was a complete specimen. These organisms were carefully removed from the rhizome and then photographed (Nikon AW130 camera) (Figure 1). The photographs were used to identify the organisms based on appropriate references.

It was noticed serendipitously that the presence of these burrows in E. acoroides rhizomes could be detected from the difference felt when gently squeezing healthy rhizomes (Figure 2e) and burrowed rhizomes (Figure 2d) between the fore-finger and thumb. This method of detection was validated by the examination of exposed $(\mathrm{n}=100)$ and nonexposed $(\mathrm{n}=100) E$. acoroides rhizomes in the natural seagrass area (September 2019). The gentle squeeze detection method was $100 \%$ accurate on this sample; however, the method could not distinguish occupied burrows from unoccupied burrows. This gentle squeeze method was then used to determine the prevalence of burrows in the rhizomes of the seagrass transplants.

To support the initial tentative identification and to gain an idea of the prevalence of this boring organism, a further eleven $E$. acoroides shoots with exposed rhizomes were collected at random using a spade on September 17, 2018. Holes (burrow openings or cross-sections similar to Figure $2 \mathrm{~b}$ or $2 \mathrm{~d}$ ) were present in all eleven rhizomes. The specimens were rinsed in seawater to remove attached sediment. Each sample was then stored in a container filled with seawater to prevent drying. The samples were then taken to the Marine Ecology Laboratory, Faculty of Marine and Fisheries Sciences, Hasanuddin University and the Takalar Brackish-water Aquaculture Laboratory for further observation. The number of burrows in each rhizome was recorded, and the approximate diameter burrow of each burrow was measured using a ruler (precision: $1 \mathrm{~mm}$ ). Burrow length could not be determined accurately as most burrows had extended beyond the sampled rhizome segment, burrows were not always straight, and the burrowed rhizomes were brittle and broke easily. Breakage occurred when attempting to make longitudinal sections to expose the burrows and the organisms within them; the burrows did not always run the whole length of the rhizome, and the endpoint could not always be identified with certainty. 


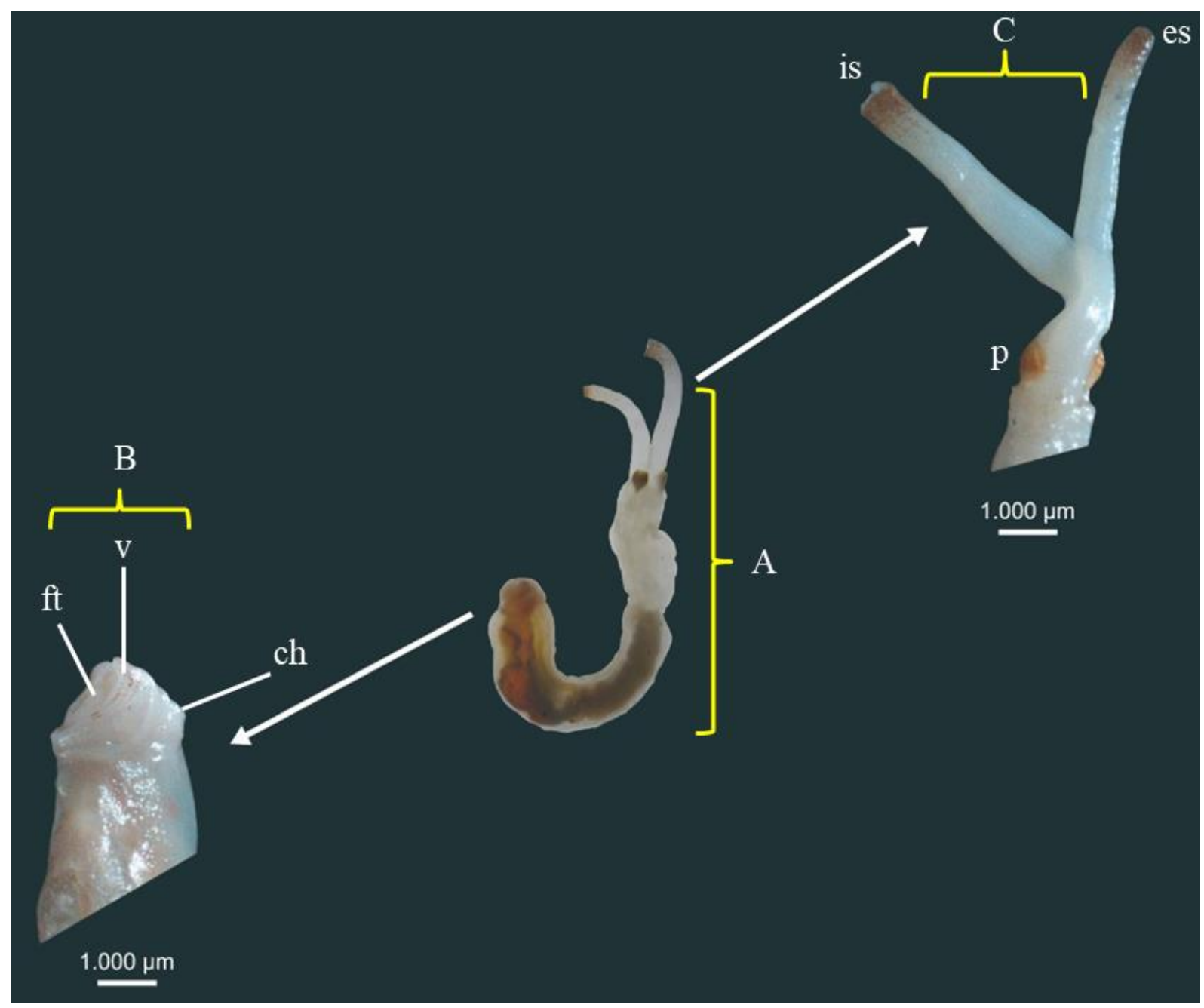

Figure 3. Boring organism found in an E. acoroides rhizome in Barrang Caddi, Spermonde Archipelago, South Sulawesi, Indonesia: A. Whole specimen; B. Anterior region (ft: foot; v: valve; ch: cephalic hood); C. Posterior region (p: pallet; is: incurrent siphon; es: excurrent siphon)

Vertical and horizontal sections were made with care, in order to avoid damaging the boring organisms which might be present within the burrows in each rhizome. Although burrows with calcareous linings (calcareous tubes) were present in all $11 \mathrm{E}$. acoroides rhizomes, only three boring organisms were found. These three specimens were preserved in $70 \%$ alcohol. The specimens were examined under stereo microscopes (Olympus SZ61 and Zeiss V8). Digital photographs (whole animals and specific body parts) with scale bars were taken through the Zeiss V8 microscope which was connected directly to a computer (e.g. Figure 3B and 3C). Photographs taken through the Olympus SZ61 microscope did not have scale bars (e.g. Figure 3A).

\section{RESULTS AND DISCUSSION}

\section{Results}

The boring organisms found in $E$ acoroides rhizomes at the study site were identified to the family level as
Teredinids, commonly known as shipworms, following the keys provided by Turner (1966). This identification was based on several morphological features including paired pallets located posteriorly and reduced double-hinged shell valves, with a vermiform body plan (Figures 3 and 4). Only the extreme end of the anterior region was encased in pair of small serrated shells (Figure 3.A and 3.C), while the rest of the body, which was soft in texture and milky white in color, was exposed (Figure 3.A) but protected by a pearly white calcareous tube lining the burrow in which the organisms were found (Figure 2.D). The outer tissues were translucent, so that the internal organs (viscera, and in particular the large gills) could be seen through the body wall (Figure 3.A and 4.D). The shell valves were denticulated as is typical in Teredinids which use the sharp serrations on these vestigial shells to drill into wooden or wood-like materials such as floating wood, mangrove roots, and seagrass rhizomes (Figure 4). A pair of paddleshaped pallets was present, flanking the base of the siphons (Figure 3.A and 3.C). These pallets are unique to the Family Teredinidae and serve to block the entrance to the 
hole when the shipworm is disturbed, and has withdrawn the paired siphons into the burrow (Shipway et al. 2016).

Based on Shipway et al. (2016), the organisms appear to belong to the genus Zachsia sp. (Figure 4), the only genus within the Teredinidae which has been reported as a seagrass rhizome borer (Velásquez and Shipway 2018). Specific diagnostic characters included the paired siphons which were predominantly white in color, with a reddish tinge near the posterior end (Figure 3.C). The anterior region of Zachsia (Figure 3.A) resembles the description in Shipway et al. (2016): "cephalic hood and foot comparatively enlarged and the shell valves reduced [...]. The foot is bulbous and extends beyond the aperture of the shell valves". Shipway et al. (2016) also describe the translucent cephalic hood, once distended, as being approximately double the size of the shell valves; this feature is not visible in Figure 3.A, as the cephalic hood shrank during preservation but was observed in a live specimen. The pallets of the specimens collected closely resemble those shown in Haga (2006) and Shipway et al. (2016); however they are noticeably different from the pallets of a specimen collected in Malaysia by Yap et al. (2018) (see Figure 4.A, 4.B, 4.H, 4.I, 4.J1, 4.J2). Dwarf males as described by Turner and Yakovlev (1983), Yakovlev and Malakhov (1985) and Shipway et al. (2016) were not seen. Brooded larvae as described by Shipway et al. (2016) were also not seen.
Each of the sampled seagrass rhizome segments collected (average length $10.5 \mathrm{~cm}$ ) contained calcareous tubes (one to four per sample) with a diameter ranging from $2 \mathrm{~mm}$ to $5 \mathrm{~mm}$ (Figure 2.D). Zachsia sp. was predominantly found in conditions where seagrass rhizomes were exposed (e.g. due to erosion of the surrounding sediment), rather than in rhizomes which were covered by (buried under) sediment. Out of the 200 rhizomes sampled in the Zachsia burrow detection method validation, burrows lined with calcareous tubes were present in $68 \%$ of exposed $E$. acoroides rhizomes $(\mathrm{n}=100)$ but only $4 \%$ of non-exposed rhizomes in the natural seagrass bed $(\mathrm{n}=100)$. Applying this method in the $E$. acoroides transplantation area, the symptomatic feel of burrow presence was detected in all exposed rhizomes but was not detected in any of the rhizomes buried in the substrate. Exposed rhizomes were common in the transplant method using metal frames, but not in the other two methods used.

We found that some E. acoroides plants infested with Zachsia showed signs of stress, both in the natural seagrass meadow and in the transplant area. The seagrass leaves and new shoots were partially or totally tawny brown in color, unlike the healthy green color of the plants without Zachsia burrows (Figure 5). Some seagrass rhizomes containing several tubes were visibly decaying and sometimes appeared dead.

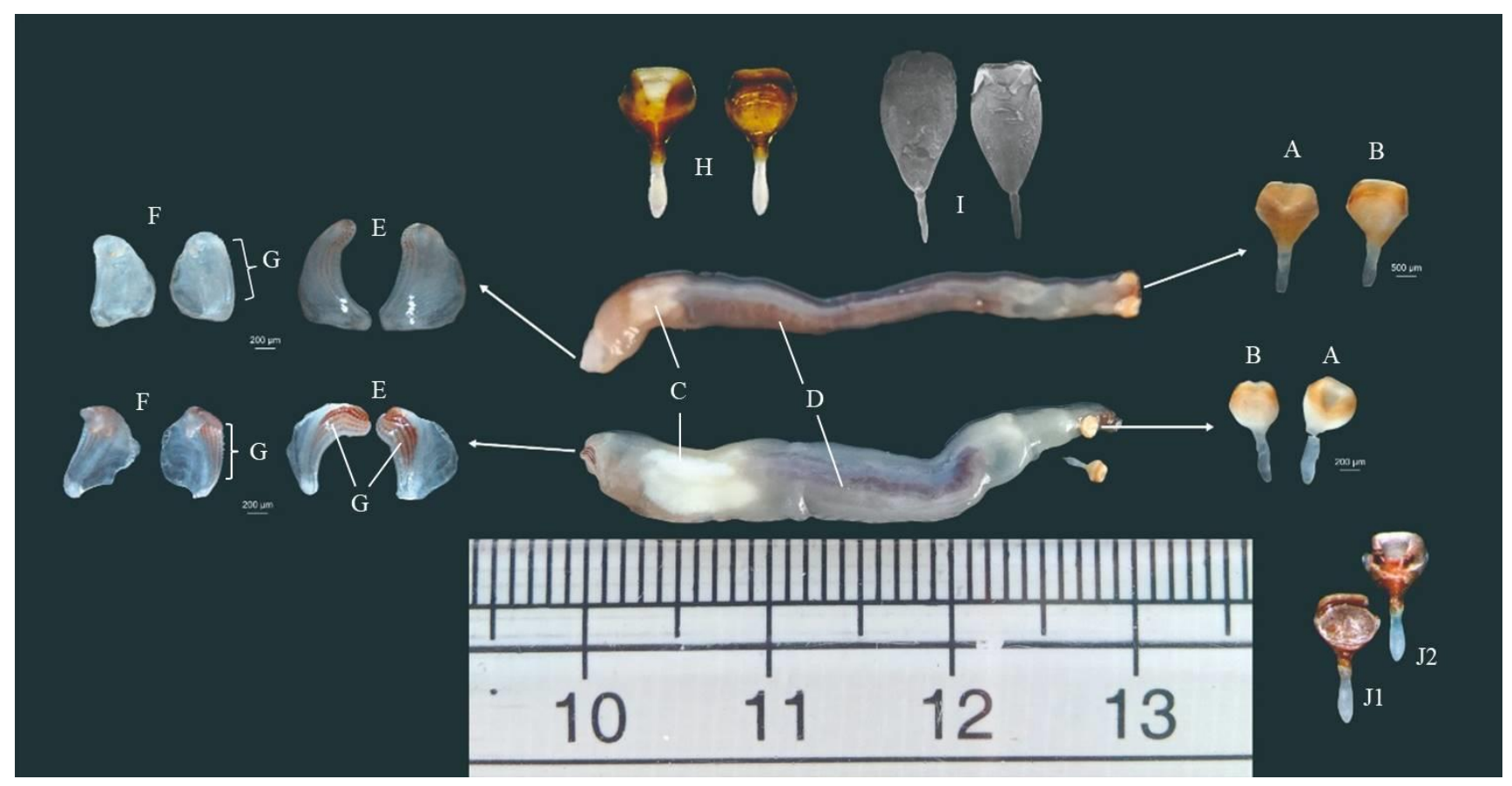

Figure 4. A. Outer margin of the calcareous pallet (this study). B. Inner margin of the calcareous pallet (this study). C. Caecum. D. Internal organs (gills visible in the lower specimen). E. Outer margin of valves. F. Inner margin of valves. G. Denticulation of shell valves. H. Collection of calcareous pallet of Zachsia zenkewitschi from Minami-Sanriku town and Ishinomaki city by T. Haga (Shipway et al. 2016, Figure 4.A). I. Calcareous pallet of Zachsia sp. From Malaysia (Yap et al. 2018, Figure 4). J1. Collection of calcareous pallet of Zachsia zenkewitschi from Shizugawa Bay (Haga 2006, Figure 1B), and J2. Collection of calcareous pallet of Zachsia zenkewitschi from Putyatin Island, Vladivostok by Bulatoff and Rjabtschikoff (Haga 2006, Figure 1.A). Note: scale bars A and B above; 500 um; A and B below: 200 um; E and F: 200um. 


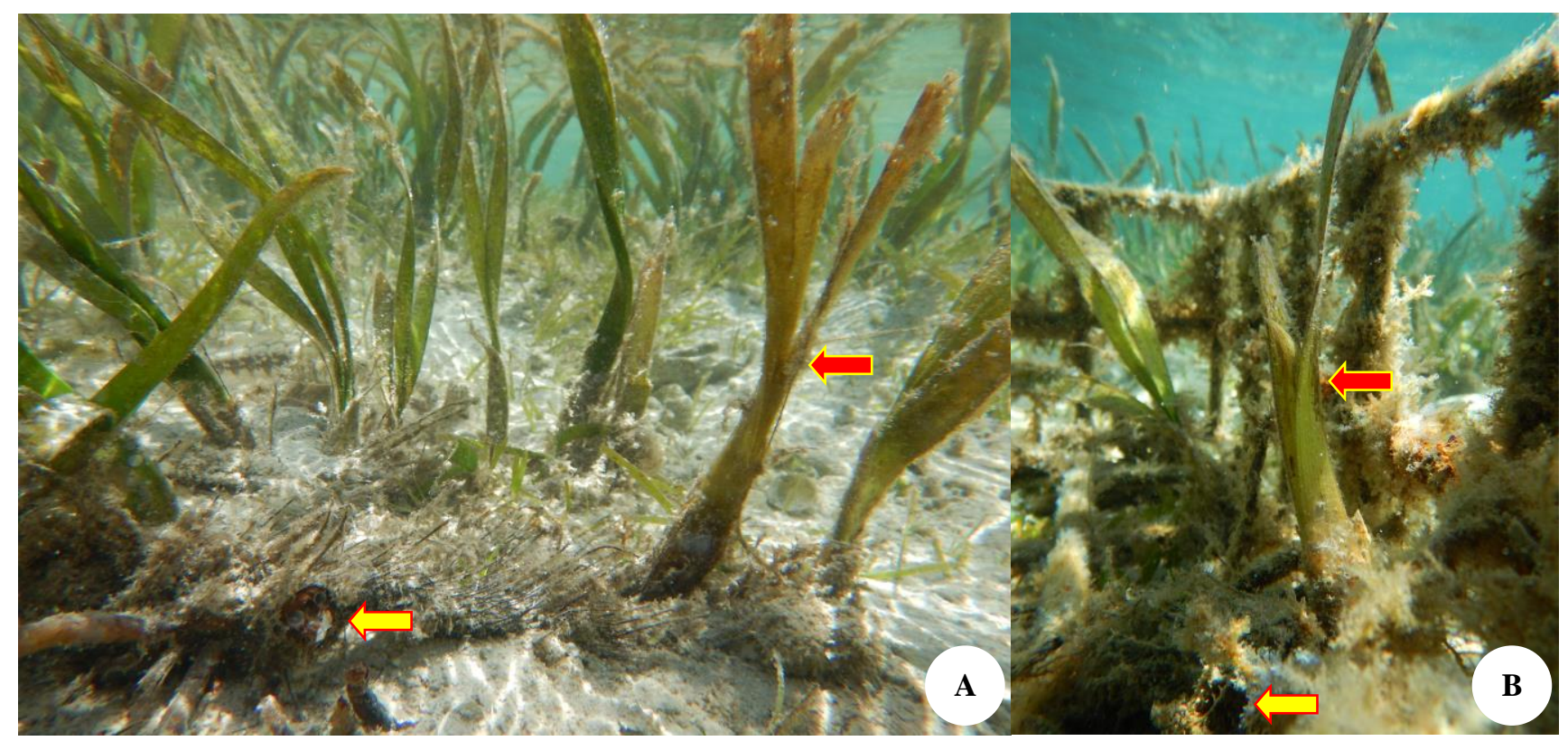

Figure 5. A. Natural seagrass, B. Seagrass transplant in the frame method restoration plot; red arrows indicate tawny brown leaves and yellow arrows indicate calcareous tubes inside exposed rhizomes

\section{Discussion}

The boring organism was found in E. acoroides rhizomes in both natural seagrass beds and in seagrass transplants within a seagrass restoration plot. This is not, however, the first record of this genus in tropical waters, as Zachsia sp. was found in Malaysia, also in rhizomes of the same seagrass species, E. acoroides (Yap et al. 2018). Although the two sites (Spermonde Archipelago, Indonesia, and Gaya Island, Malaysia) are relatively close, and both within the Southeast Asian region, it is possible that the organisms found may belong to different species. The morphology of Zachsia sp. reported from Malaysia appears to have several differences compared with the Indonesian samples. The pallet of Zachsia sp. found in Malaysia appears more elongated with a U-shape and a short stalk, while the pallets of the Indonesian specimens in this study were wider, with a diamond shape and longer stalk (see Figure 4.A, 4.B, 4.I). The pallet shape of the specimens in this study was more similar in shape to those of Zachsia zenkewitschi from Japan and Russia (see Figure 4.A in Haga (2006); Shipway et al. (2016); Turner et al. (1983)). Intraspecific variation in the pallets of Teredinidae species has well documented, being principally attributed to their boring lifestyle and environmental conditions (Borges et al. 2012; Velásquez and López 2015). This is one considered one of the principal reasons for erroneous identifications in the past, as demonstrated by a large number of synonym species names (Turner 1966). Zachsia zenkewitschi is the only species of the genus Zachsia which has been fully described based on morphological and DNA (18S and $28 \mathrm{~S}$ subunit nuclear rRNA genes) traits. The observed morphological differences are not sufficient as a basis for determining the species of the organisms cofound in the Spermonde Archipelago. Therefore, more detailed observations and molecular (DNA) research are required to determine the species of the Zachsia specimens observed in our study.

Although Zachsia zenkewitschi has only been reliably identified to date in temperate seagrasses, it is possible that this species could have a wider distribution, as suggested by Haga (2006) and Yap et al. (2018). Other shipworms have been transported across seas and ocean basins by ships (Shipway et al. 2014) as well as natural events. For example, debris from the Japanese tsunami in 2011 transported living shipworms identified as belonging to eight species to the Northeastern Pacific and Hawaiian shores (Treneman et al. 2018). Furthermore, seagrass rhizomes with live Zachsia have been found drifting at sea (Haga 2006). With respect to the possibility of a localized introduction of Zachsia through the movement of transplants from one island to another, it is impossible to be certain whether or not any Zachsia were originally present in the transplants. However, the ubiquitous presence of Zachsia in exposed transplant rhizomes and absence of Zachsia in non-exposed transplant rhizomes, coupled with a similar pattern in the natural seagrass, points towards a pre-existing Zachsia population in the seagrasses around Barrang Caddi. It seems unlikely that all the Zachsia in the natural seagrass around Barrang Caddi were the result of a very recent and small-scale introduction via the transplants. However, Zachsia has recently been found around Barrang Lompo (Safruddin 2019, personal communication). The Spermonde Archipelago is situated in Makassar Strait, a seaway traversed by major global shipping lanes (Wajsowicz et al. 2003) as well as the Indonesian Throughflow (Barber et al. 2006), presenting many opportunities for the dispersal of species such as Zachsia. It is possible that Zachsia may be widespread in the 
Spermonde Archipelago, either as a native or introduced (alien) species.

The presence of calcareous tubes inside seagrass rhizomes may affect seagrass health, growth, and survival. Seagrass rhizomes are not only used for vegetative propagation, but also to store energy (Hemminga 1998). The diet of Zachsia zenkewitschi in Vostok Bay, Russia, was found to consist almost entirely of seagrass rhizomes (Kiyashko 1986). It can thus be assumed that the boring activity of Zachsia will inevitably reduce the volume of rhizome in which food can be stored, as well as making the rhizomes more brittle and likely to break, with negative consequences for survival and spread. Some of the rhizomes of natural and transplanted seagrass shoots that had died were found to have calcareous tubes inside. The possible presence of Zachsia was unknown and therefore not recorded in the earlier stages of the transplantation experiment. Therefore these observations are qualitative and we do not have statistical data to estimate how survival of the transplants may have been affected over time by the boring activities of Zachsia.

Zachsia has been reported to substantially reduce the growth of $E$. acoroides shoots growing from infested rhizomes (Yap et al. 2018). We hypothesize that the seagrass shoots may not be able to obtain and/or store sufficient nutrients due to the hollowing out and breakage of the rhizomes. Even though the seagrass plants should obtain nutrition from photosynthesis, we observed signs of stress in the leaves of some affected transplants, in particular, a change in color from green to mostly tawny brown (Figure 5). However, if the burrows occupy too large a proportion of the rhizome, they are likely to cause breakage of the rhizome, in which case the borers themselves would become exposed and vulnerable to predation. Thus, there is a level of infestation beyond which both host and parasite may experience high mortality. The opportunistic observations reported here are qualitative, and further research is called for to explore the true effects of these borers on the health and survival of seagrasses.

The presence of Zachsia sp. in the study area appears to occur mainly in seagrass rhizomes which have become exposed (visible above the predominantly sandy substrate). Turner et al. (1983) also mentioned repeatedly the finding of Zachsia in exposed rhizomes (in this case exposed from a muddy substrate). Seagrass rhizomes can become exposed due to both natural (e.g. wave action) and anthropogenic causes. In the study area, there were indications of sand mining by local people in and around the natural seagrass beds; the hollows made tend to become enlarged due to wave action. Within the seagrass transplantation plots, the exposure of seagrass rhizomes was related to the method of planting. In the frame planting method, where the shoots were attached to a metal frame, the rhizomes were laid on top of substrate without any attempt to bury the rhizomes or to cover them with sand. Signs of Zachsia sp. burrows were ubiquitous in this treatment but not found in the two treatments where the rhizomes were buried.
It is worth remembering that Zachsia zenkewitschi was found by Haga (2006) in seagrass rhizomes which were drifting, and therefore exposed to attack by organisms in the water column, unlike seagrass rhizomes under a (possibly protective) layer of sediment. In a laboratory experiment observing the dispersal and settlement of Zachsia larvae over short distances, it was found that Zachsia larvae were more likely to swim close to the substrate, rather than higher in the water column (Turner and Yakovlev 1983; Turner et al. 1983). Thus, any dispersing larvae could be expected to encounter (and therefore be likely to settle on) any exposed rhizomes. Although the initial source of the Zachsia sp. which became boring pests in the seagrass transplants during this study cannot be ascertained, it seems likely that these molluscs are widespread in natural seagrass beds. Furthermore, wherever larvae are present in the water column, the prevalence of Zachsia could be expected to be higher if disturbance has caused seagrass rhizomes to become exposed. Although further experimental verification is required, our findings indicate that seagrass restoration is more likely to succeed if the transplant rhizomes are buried in the substrate, and if disturbance to nearby natural seagrass beds is minimized (e.g. through cessation of sand mining).

Our findings contribute important information for seagrass conservation, especially seagrass restoration in both temperate and tropical regions, in particular regarding the existence and distribution of seagrass boring molluscs (Zachsia sp.). Avenues for further research include specieslevel identification and a better understanding of their role in and impact on seagrass ecosystems.

\section{ACKNOWLEDGEMENTS}

We dedicate this paper to our mentor Susan L. Williams who sadly passed away much too early in April 2018. We gratefully thank Nur Tri Handayani for discussion and assistance in the field and lab, Fathul Ash Shiddiqegy and Gunawan Safruddin for their patience and help during fieldwork, Abigail M. Moore for assistance with English language and Zuhrizal for assistance in preparing the images. We are also grateful to Reuben Shipway and Tzuen Kiat Yap who assisted in identification our samples and Yuri Yakovlev who provided us with valuable references and input, as well as six anonymous reviewers whose comments and advice significantly improved the article, and the Editor-in-Chief. This study was supported by a PMDSU scholarship from the Ministry of Research, Technology and Higher Education of the Republic of Indonesia (contract number 132/SP2H/LT/DRPM/IV/ 2017).

\section{REFERENCES}

Barber PH, Erdmann MV, Palumbi SR. 2006. Comparative phylogeography of three codistributed stomatopods: Origins and timing of regional lineage diversification in the coral triangle. Evolution 60 (9): 1825-1839. 
Borges LMS, Sivrikaya H, Roux A, Shipway JR, Cragg SM, Costa FO. 2012. Investigating the taxonomy and systematics of marine wood borers (Bivalvia: Teredinidae) combining evidence from morphology, DNA barcodes and nuclear locus sequences. Invertebr Syst 26: 572582. DOI: $10.1071 / \mathrm{IS} 12028$

Brearley A, Kendrick GA, Walker DI. 2008. How does burrowing by the isopod Limnoria agrostisa (Crustacea: Limnoriidae) affect the leaf canopy of the southern Australian seagrass Amphibolis griffithii? Mar Biol 156: 65-77. DOI: 10.1007/s00227-008-1065-1

Bulatoff GA, Rjabtschikoff PI. 1933. Eine neue Ggattung aus de familie der Teredinidae aus dem Japanischen meer. Zool Anz 104: 165-176.

de la Torre-Castro M, Eklöf JS, Rönnbäck P Björk M. 2008. Seagrass importance in food provisioning services : Fish stomach content as a link between seagrass meadows and local fisheries. West Indian Ocean J Mar Sci 7 (1): 95-110.

den Hartog C. 1970. The seagrass of the world. North-Holland Publishing Company, Amsterdam, The Netherlands.

Duarte CM. 2002. The future of seagrass meadows. Environ Conserv 29 (2): 192-206. DOI: 10.1017/S0376892902000127

Duarte CM, Kennedy H, Marbà N, Hendriks I. 2013. Assessing the capacity of seagrass meadows for carbon burial: Current limitations and future strategies. Ocean Coast Manag 83: 32-38. DOI: 10.1016/j.ocecoaman.2011.09.001

Duffy JE. 2006. Biodiversity and the functioning of seagrass ecosystems. Mar Ecol Prog Ser 311: 233-250.

Fourqurean JW, Duarte CM, Kennedy H, Marbà N, Holmer M, Mateo MA, Apostolaki ET, Kendrick GA, Krause-jensen D, McGlathery KJ and Serrano O. 2012. Seagrass ecosystems as a globally significant carbon stock. Nat Geosci 5 (7): 505-509. DOI: 10.1038/ngeo1477

Fourqurean JW, Manuel S, Coates KA, Kenworthy WJ and Smith SR 2010. Effects of excluding sea turtle herbivores from a seagrass bed Overgrazing may have led to loss of seagrass meadows in Bermuda. Mar Ecol Prog Ser 419: 223-232. DOI: 10.3354/meps08853

Gacia E, Duarte CM, Marba N, Terrados J, Kennedy H, Fortes MD, Tri N 2003. Sediment deposition and production in SE-Asia seagrass meadows. Estuar Coast Shelf Sci 56: 909-919. DOI: 10.1016/S0272$7714(02) 00286-X$

Gambi MC. 2002. Spatio-temporal distribution and ecological role of polychaete borers of Posidonia oceanica (L.) delile scales. Bull Mar Sci 71 (3), 1323-1331.

Gambi MC, Lorenti M. 2009. First record of borer organisms associated to the seagrass Thalassia hemprichii (Mafia Island, Tanzania). Biol Mar Mediterranian 16 (1): 264-265

Gambi M, Trani B, Buia MC, Cristina M. 2005. Taxonomic diversity and distribution of polychaete and isopod borers on the sheaths of the seagrass Posidonia oceanica: analysis at regional scale along the coast off Sardinia (Italy). Ital J Zool 72: 141-151. DOI: $10.1080 / 11250000509356664$

Guidetti P. 2000. Invertebrate borers in the Mediterranean seagrass Posidonia oceanica : biological impact and ecological implications. J Mar Biol Assoc UK 80: 725-730.

Haga T. 2006. The rhizome-boring Shipworm Zachsia zenkewitschi (Bivalvia: Teredinidae) in drifted eelgrass. VENUS 65 (3): 263-266.

Hemminga MA. 1998. The root/rhizome system of seagrasses : An asset and a burden. J Sea Res 39: 183-196.

Hossain MS, Hashim M, Bujang JS, Zakaria MH, Muslim AM. 2018 Assessment of the impact of coastal reclamation activities on seagrass meadows in Sungai Pulai estuary, Malaysia, using Landsat data (1994-2017). Intl J Remote Sens 1-35. DOI: 10.1080/01431161.2018.1547931

Iannotta MA, Patti FP, Ambrosino M, Procaccini G, Gambi MC. 2007. Phylogeography of two species of Lysidice (Polychaeta, Eunicidae) associated to the seagrass Posidonia oceanica in the Mediterranean Sea. Mar Biol 150: 1115-1126. DOI: 10.1007/s00227-006-0405-2

Kiyashko SI. 1986. The diet of Zachsia zenkewitschi (Bivalvia: Teredinidae), investigated by the ${ }^{13} \mathrm{C}:{ }^{12} \mathrm{C}$ method. Asian Mar Biol 3: 139-143.

Lanyon JM, Limpus CJ, Marsh H. 1989. Dugong and Turtles: grazers in the seagrass system. In: Larkum AWD, McComb AJ, Shepherd S (eds.). Biology of Australian Seagrasses an Australian Perspective. Elsevier, Amsterdam.

Lavery PS, Mateo MA, Serrano O, Rozaimi M. 2013. Variability in the carbon storage of seagrass habitats and its implications for global estimates of blue carbon ecosystem service. PLoS ONE 8 (9): 1-12 DOI: 10.1371 /journal.pone. 0073748
Lebreton B, Richard P, Radenac G, Bordes M, Bre M, Blanchard F, Arnaud C, Mornev E, Blanchard FG. 2009. Are epiphytes a significant component of intertidal Zostera noltii beds? Aquat Bot 91: 82-90. DOI: 10.1016/j.aquabot.2009.03.003

Les DH, Cleland MA. 1997. Phylogenetic studies in Alismatidae, II: evolution of marine angiosperms (seagrasses) and hydrophily. Syst Bot 22 (3): 443-463.

Marba N, Arias-Ortiz A, Masqu P, Kendrick GA, Mazarrasa I, Bastyan GR, Garcia-Orellana J, Duarte CM. 2015. Impact of seagrass loss and subsequent revegetation on carbon sequestration and stocks. J Ecol 103: 296-302. DOI: $10.1111 / 1365-2745.12370$

Mejaes BA, Poore AGB, Thiel M. 2015. Crustaceans inhabiting domiciles excavated from macrophytes and stone. In: Lifestyle and feeding biology (pp. 118-144).

Moore AM, Ambo-Rappe R, Ali Y. 2017. "The Lost Princess" (putri duyung)" of the Small Islands: Dugongs around Sulawesi in the Anthropocene. Front Mar Sci 4: 1-16. DOI: 10.3389/fmars.2017.00284

Olsen JL, Rouzé P, Verhelst B, Lin YC, Bayer T, Collen J, Dattolo E, de Paoli E, Dittami S, Maumus F, Michel G, Kersting A, Lauritano C, Lohaus R, Topel M, Tonon T, Vanneste K, Amirebrahini M, Brakel J, Bostrom C, Chovatia M, Grimwood J, Jenkins JW, Jueterbock A, Mraz A, Stam W, Tice H, Bornberg-bauer E, Green PJ, Pearson GA, Procaccini G, Duarte CM, Schmutz J, Reusch TBH, ven de Peer, Y. 2016. The genome of the seagrass Zostera marina reveals angiosperm adaptation to the sea. Nature 530: 331-335. DOI: $10.1038 /$ nature 16548

Rossini EA, Rueda JL, Tibbetts IR. 2014. Feeding ecology of the seagrass-grazing nerite Smaragdia souverbiana (Montrouzier, 1863) in subtropical seagrass beds of Eastern Australia. J Molluscan Stud 80: 139-147. DOI: $10.1093 /$ mollus/eyu003

Shipway JR, Borges LMS, Muller J, Cragg SM. 2014. The broadcast spawning Caribbean shipworm, Teredothyra dominicensis (Bivalvia, Teredinidae), has invaded and become established in the eastern Mediterranean Sea. Biol Invasions 12. DOI: 10.1007/s10530-0140646-9

Shipway JR, O'Connor R, Stein D, Cragg SM, Korshunova T, Martynov A, Haga T, Distel DL. 2016. Zachsia zenkewitschi (Teredinidae), a rare and unusual seagrass boring bivalve revisited and redescribed. PLoS ONE 11 (5): 1-12. DOI: 10.1371/journal.pone.0155269

Short FT, Polidoro B, Livingstone SR, Carpenter KE, Bandeira S, Bujang JS, Calumpong HP, Carruthers TJB, Coles RG, Dennison WC, Erftemeijer PLA, Fortes MD, Freeman AS, Jagtap TG, Kamal AHM, Kendrick GA, Kenworthy WJ, La Nafie YA, Nasution IM, Orth RJ, Prathep A, Sanciangco JC, van Tussenbroek B, Vergara SG, Waycott $\mathrm{M}$ and Zieman, JC. 2011. Extinction risk assessment of the world's seagrass species. Biol Conserv 144: 1961-1971. DOI: 10.1016/j.biocon.2011.04.010

Treneman NC, Borges LMS, Shipway JR, Raupach MJ, Altermark B, Carlton JT. 2018. A molecular phylogeny of wood-borers (Teredinidae) from Japanese tsunami marine debris. Aquat Invasions 13 (1): 101-112. DOI: $10.3391 /$ ai.2018.13.1.08

Turner RD. 1966. A survey and Illustrated Catalogue of the Teredinidae (Mollusca: Bivalvia). The Museum of Comparative Zoology, Harvard University, Cambridge.

Turner RD, Yakovlev YM. 1983. Dwarf males in the Teredinidae (Bivalvia, Pholadacea). Science 219 (3): 1077-1078

Turner RD, Yakovlev YM, Karaseva EM. 1983. Some aspects of the life history of Zachsia zenkewitschi (Teredinidae, Bivalvia). Biol Morya 5 (5): 257-264.

Unsworth RKF, Ambo-rappe R, Jones BL, La nafie YA, Irawan A, Hernawan UE, Moore AM and Cullen-Unsworth L. 2018. Indonesia's globally significant seagrass meadows are under widespread threat. Sci Tot Environ 634: 279-286. DOI: 10.1016/j.scitotenv.2018.03.315

Velásquez M, López I. 2015. Revista Mexicana de biodiversidad first record of Spathoteredo spatha (Mollusca: Teredinidae) in Venezuela. Rev Mex de Biodiversidad 86 (1): 262-264. DOI: $10.7550 / \mathrm{rmb} .46308$

Velásquez M, Shipway J. 2018. A new genus and species of deep-sea wood-boring shipworm (Bivalvia: Teredinidae) Nivanteredo coronata n. sp. from the Southwest Pacific. Mar Biol Res 1-11. DOI: $10.1080 / 17451000.2018 .1544421$

Wajsowicz RC, Gordon AL, Field A, Susanto RD. 2003. Estimating transport in Makassar Strait. Deep-Sea Res II 50: 2163-2181. DOI: 10.1016/S0967-0645 (03)00051-1.

Waycott M, Duarte CM, Carruthers TJB, Orth RJ, Dennison WC, Olyarnik S, Calladine, A, Fourqurean JW, Heck KL, Hughes AR, 
Kendrick GA, Kenworthy WJ, Short FT, Williams SL. 2009. Accelerating loss of seagrasses across the globe threatens coastal ecosystems. Proc Natl Acad Sci USA 106 (30): 12377-12381. DOI: 10.1073/pnas.0905620106

Williams SL. 2007. Introduced species in seagrass ecosystems: Status and concerns. J Exp Mar Biol Ecol 350: 89-110. DOI: 10.1016/j.jembe.2007.05.032
Yakovlev YM, Malakhov V. 1985. The anatomy of dwarf males of Zachsia zenkewitschi. Asian Mar Biol 1985 (1): 47-56.

Yap TK, Gallagher JB, Saleh E, Admodisastro VA. 2018. The occurrence of boring bivalve (Genus: Zachsia), in a tropical seagrass meadow in Gaya Island (Sabah, Malaysia) and its possible ecological implications. Borneo J Mar Sci Aquacult 2 (12): 48-53. 